\title{
A history of health and medical research in Australia
}

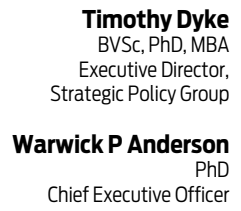

National Health and Medical Research Council, Canberra, ACT.

timothy.dyke@ nhmrc.gov.au

doi: 10.5694/mjal4.00347
. ealth and medical research has significantly contributed to improvements in human health and wellbeing throughout the world, and Australia has played its part. As a result of this research, Australians have benefited by remaining healthier for longer through better treatments and improved health care, and from contributions to national wealth through the development of innovative industries. Despite the significant role of research in Australia, there have been few specific compilations on the Australian history of health and medical research. This article is a brief overview of Australian health and medical research, with the role of the National Health and Medical Research Council (NHMRC) as a main focus.

\section{The early years}

Before the 1900s, medical research efforts of Australian scientists were focused on Australian flora, parasitology and bacteriology. ${ }^{1}$ Early accounts record significant observations made by medical practitioners on unique or emerging diseases that then led to major advances in medical knowledge. Examples include observations on smallpox in the late 1700s, successful smallpox vaccination by John Savage and Thomas Jamison in the early 1800s, and Harry Allen's study of the pathology of syphilis as well as John Thomas's work on hydatid disease in the late 1800s. ${ }^{2}$

In 1862, the University of Melbourne began teaching its first medical students, followed by the University of Sydney in 1883, and other states and territories over time. At first, most research was done in traditional academic departments but, increasingly, it was carried out in dedicated research centres and institutes.

\section{Australian research in the 20th century}

Independent medical research institutes have long been a distinctive feature of Australian health and medical research. In 1910, the first formal medical research facility, the Australian Institute of Tropical Medicine, was established in northern Queensland, ${ }^{3}$ closely followed by the founding of the Walter and Eliza Hall Institute in Melbourne in 1915.

The establishment of the NHMRC in 1936 was arguably the most significant event between the two World Wars for medical research here. The NHMRC was established to better understand and treat the causes of diseases, including "vitamins, viruses, endocrine disorders". ${ }^{4}$ In defining the scope of the new Council, the Minister for Health, William Hughes, said "Research must be actively pursued and developed, and as fast as new knowledge is acquired it must be applied". ${ }^{5}$ This early recognition that the role of a body such as the NHMRC was to support discovery research and also to work to achieve the benefits of research for the community has remained an important focus for the NHMRC over its almost eight decades and is expressed as a priority action in its current strategic plan. ${ }^{6}$
Summary

Health and medical research has played an important role in improving the life of Australians since before the 20th century, with many Australian researchers contributing to important advances both locally and internationally.

- The establishment of the National Health and Medical Research Council (NHMRC) to support research and to work to achieve the benefits of research for the community was significant.

The NHMRC has also provided guidance in research and health ethics.

- Australian research has broadened to include basic biomedical science, clinical medicine and science, public health and health services.

- In October 2002, the NHMRC adopted Indigenous health research as a strategic priority.

In 2013, government expenditure through the NHMRC was $\$ 852.9$ million.

This article highlights some important milestones in the history of health and medical research in Australia.

Examples of research advances between 1900 and 1950 include: 2,7

- epidemiological studies on the 1900 Sydney plague outbreak - John Thompson

- development of the first portable electrocardiograph Edward Both

- development of a respirator — Edward and Donald Both

- treatment of bipolar disorders with lithium - John Cade

- isolation of a strain of the influenza A virus — Sir Frank Macfarlane Burnet

- better understanding of malaria and development of an antimalarial drug — Sir Neil Fairley.

Examples of research advances between 1950 and 2000 are listed in Box 1.7

\section{International collaborations}

From the early days of the 19th century, medical researchers in Australian universities (and then independent institutes and hospitals) have corresponded and collaborated with researchers and health professionals overseas. ${ }^{8}$ Such collaboration has continued, and the extent of international collaboration has nearly doubled over the past 20 years. In the period 2005-2009, 41\% of Australian health and medical research publications involved international collaboration, ${ }^{9}$ compared with $21 \%$ during $1993-1994 .^{10}$

\section{Research ethics and integrity}

Australia has had standards and guidelines on research ethics and integrity for over 50 years. 
1 Examples of Australian health and medical advances between 1950 and $2000^{7}$

Advance

Lead researchers

Discovery that kuru disease in Papua New Guinea was transmitted Michael Alpers via cannibalistic practices

Identification of rotavirus

Isolation of inhibin

Purification of granulocyte-macrophage colony-stimulating factor

Development of an artificial heart valve

Prevention of spina bifida with folate

Development of a multichannel cochlear implant

Discovery of neuraminidase inhibitors for influenza

Describing a major risk factor for sudden infant death syndrome

Leadership of the World Health Organization campaign for the eradication of smallpox

Advancement of the understanding of the role of antibodies in the immune system

Discovery of the link between headache powders and kidney damage

Development of antivenoms for spider and snake bites

Discovery of Helicobacter pylori and its role in gastritis and peptic ulcer disease

Investigation and naming of Q fever, leading to identification of Coxiella burnetii bacterium

Defining the role of neuropeptides in hypertension

Discovery of the role of the thymus in the immune system

Demonstration of chemical synaptic transmission being

responsible for most central and peripheral synapses

Identification of links between fragile sites of chromosomes and intellectual disability

Development of in vitro fertilisation

Ruth Bishop, Ian Holmes

Henry Burger

Antony Burgess, Donald Metcalf

Victor Chang

Fiona Stanley

Graeme Clark

Peter Colman, Mark von Itzstein, Graeme Laver

Terry Dwyer

Frank Fenner

Gustav Nossal

Priscilla Kincaid-Smith

Struan Sutherland

Barry Marshall, Robin Warren

Edward Derrick

Frederick Mendelsohn

Jacques Miller

John Eccles

Grant Sutherland

Carl Wood

National guidance on general scientific practice and responsibilities began with the NHMRC statement on scientific practice (1990) ${ }^{11}$ and the Australian Vice-Chancellors' Committee's Guidelines for responsible practice in research and problems of research misconduct (1990). ${ }^{12}$ The current Australian code for the responsible conduct of research (2007) ${ }^{13}$ provides extensive guidance on the responsibilities of institutions and researchers when conducting research, and a framework for investigating allegations of research misconduct.

The current National statement on ethical conduct in human research (2007) ${ }^{14}$ was preceded by numerous guidance materials, initially the NHMRC's Statement on human experimentation issued in $1966 .^{15}$

The NHMRC first published a code to guide the use of animals in research in 1969,16 and such codes have been revised regularly, most recently in 2013. ${ }^{17}$

The NHMRC also administers the legislation passed by the Australian Parliament in 2002 (and since amended) on the use of human embryos in research and prohibition of human cloning for reproductive purposes.

\section{Areas of health and medical research}

After a restricted early focus of research, ${ }^{1}$ Australian health and medical research has broadened and today includes basic biomedical science, clinical medicine and science, public health and health services. This is evidenced by the Australian Government's expenditure on health and medical research through the NHMRC in 2013 that totalled \$852.9 million, including \$365.1 million for basic biomedical science, $\$ 282.9$ million for clinical medicine and science, \$120.4 million for public health and \$42.1 million for health services.

\section{Research involving Aboriginal and Torres Strait Islander peoples}

Early research involving Indigenous people was largely observational. ${ }^{8}$ In October 2002, the NHMRC adopted Indigenous health research as a strategic priority and made a commitment to allocate at least $5 \%$ of the medical research endowment account to Indigenous health. Between 1995 and 2013, the NHMRC funded over $\$ 410$ million in research of relevance to the health of Aboriginal and Torres Strait Islander people.

Research into the health of Aboriginal and Torres Strait Islander people receives particular focus in the NHMRC's consideration of grants, through assessment against the specific criteria of community engagement, benefit, sustainability and transferability, building capability, priority and significance. Further, the NHMRC has published guidance on ethical conduct in Aboriginal and Torres Strait Islander health research. ${ }^{18}$

Much remains to be done to better ensure that research is conducted with the consent and participation of Indigenous (and other) communities and that the findings from research are used to improve the health of Aboriginal and Torres Strait Islander people.

\section{Leaders in Australian health and medical research}

There are seven Australian-born Nobel laureates in medicine or physiology, five of whom conducted their research wholly or partly in Australia: ${ }^{19}$

- 2005 - Barry Marshall and Robin Warren for discovering the bacterium Helicobacter pylori and its role in gastritis and peptic ulcer disease

- 1996 - Peter Doherty for discoveries concerning the specificity of the cell-mediated immune defence

- 1963 - Sir John Eccles for discoveries concerning the ionic mechanisms involved in excitation and inhibition in the peripheral and central portions of the nerve cell membrane

- 1960 - Sir Frank Macfarlane Burnet for discovering acquired immunological tolerance.

Other Australians who have won a Nobel Prize for research conducted outside Australia include Elizabeth Blackburn (2009) and Howard Florey (1945).

Community support and recognition of health and medical research has been high in recent decades. This is indicated by the number of Australian researchers who have been made Australians of the Year, including Sir Frank Macfarlane Burnet (1960) and Sir John Eccles (1963), and in more recent years, Peter Doherty (1997), Sir Gustav Nossal (2000), Fiona Stanley (2003), Ian Frazer (2006) and Patrick 
2 Milestones in government funding and administration of research in Australia through the National Health and Medical Research Council (NHMRC), 1937-2013

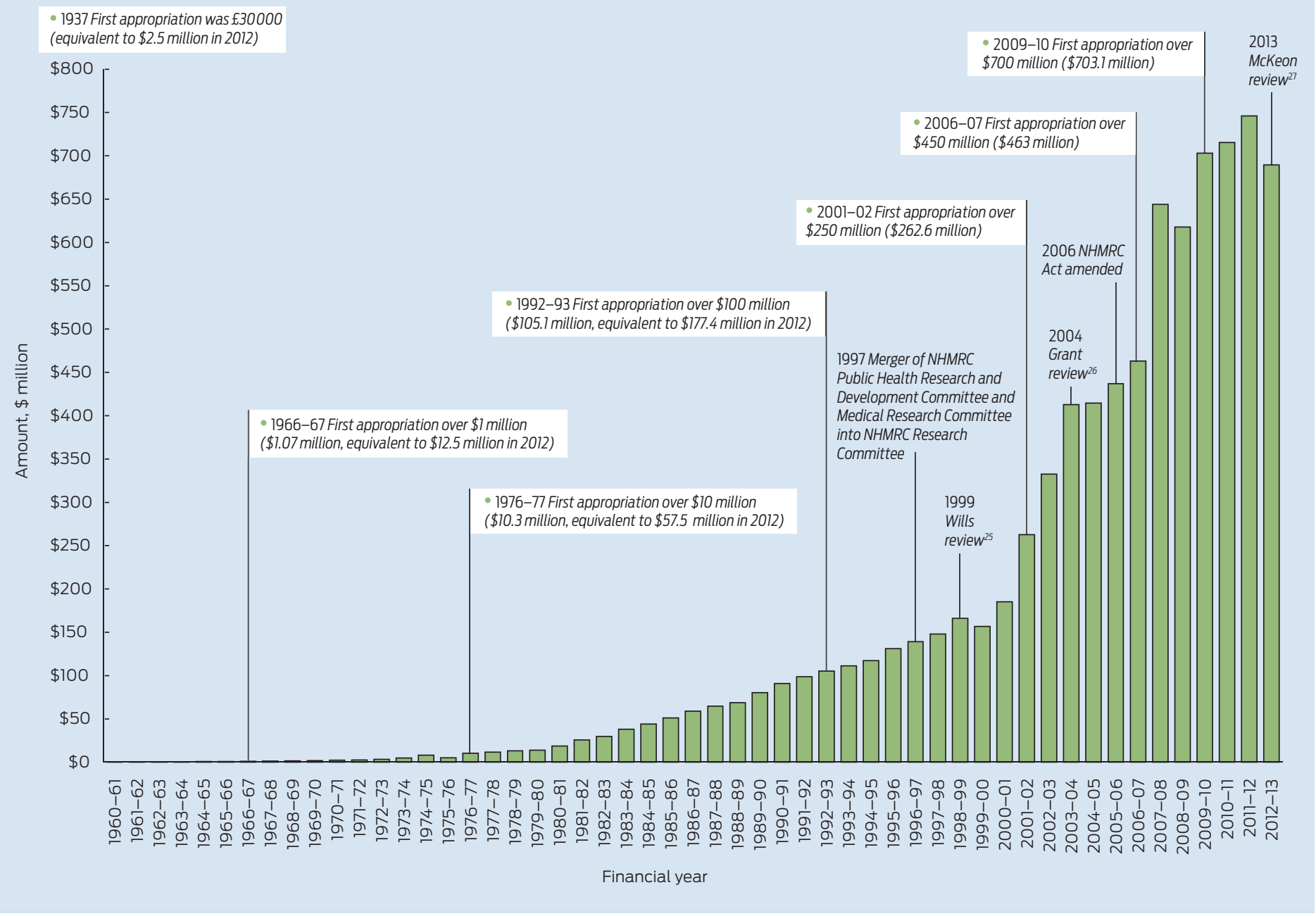

McGorry (2010) - all of whom have been supported in their research careers by NHMRC funding.

Australian health and medical research rates highly against international benchmarks. Bibliometric analyses of Australian health and medical research publications for the past two decades have demonstrated the international competitiveness of Australian health and medical researchers. $8,20,21-23$

\section{Government funding of health and medical research through the NHMRC}

From 1937 until 2013, the Australian Government, through the NHMRC, has appropriated an estimated $\$ 8.46$ billion for health and medical research (adjusted for inflation). In 2013, research expenditure through the NHMRC was $\$ 852.9$ million, compared with total health funding of $\$ 140.2$ billion in 2011-2012. ${ }^{24}$ Some key funding milestones are outlined in Box 2.

Government reviews of Australian health and medical research and of NHMRC funding, ${ }^{25-27}$ as well as independent reviews commissioned by the NHMRC ${ }^{28-30}$ in recent years, have recommended and led to improvements to the research framework in Australia.
The NHMRC has been an innovative funder. It has implemented novel research funding approaches in efforts to encourage the faster translation of research into health policy and clinical practice. For example, Centres of Clinical Research Excellence were introduced in the 1990s and expanded to cover public health and health services research excellence in 2010; and Practitioner Fellowships for researchers delivering health care were introduced in 2000. Starting in 2009, the NHMRC's Partnerships for Better Health initiatives introduced two flexible models for policy and practice research, cofunding these with organisations (from the government, non-government and private sectors) that have a need for research to inform their work. Support for early and mid career researchers across biomedical, clinical and population health research has been a feature for a decade, and the NHMRC's longstanding Research Fellowship scheme has been an important factor in growth of the medical research sector over more than three decades.

The NHMRC was also one of the earliest funders to introduce specific criteria for peer review into its grant assessment practices, predating the recent call for this in the San Francisco Declaration on Research Assessment. ${ }^{31}$ 


\section{Research in the 21st century and conclusions}

The success of Australian researchers in contributing to major advances continues in this century. Already, Australian researchers have led developments in vaccines against human papillomavirus, malaria and group A streptococcus; have developed spray-on skin cells for burns victims; and have led discoveries in genetics (eg, human enhancer sequences in DNA and functions for "junk DNA"). ${ }^{7}$

Countries with a high-quality health system need an active, involved health and medical research effort. The challenge put by Hughes in 1936 remains — that research must be actively pursued and developed, and as fast as new knowledge is acquired it must be applied.

Competing interests: We are both NHMRC employees.

Provenance: Commissioned; externally peer reviewed.

1 Morison P. Australian medical science before 1900. In: Isolated cases: 100 years of Australian medical research. Sydney: Royal Prince Alfred Hospital, 2010.

2 Gandevia B. The pattern of Australian medical history. Proc Royal Soc Med 1957; 50: 591-598.

3 Leggat PA. A college of tropical medicine for Australasia. Med J Aust 1992; 157: $222-223$

4 Doyle AE. A survey of Australian achievements in medical research. A report to the National Health and Medical Research Council. Melbourne: 1989.

5 Cumpston JHL. The health of the people; a study in federalism. Canberra: Roebuck Society, 1978.

6 Australian Government National Health and Medical Research Council. NHMRC Strategic Plan 2013-2015. Canberra: NHMRC, 2012.

7 National Health and Medical Research Council. High achievers in health and medical research. http://www.nhmrc.gov.au/high-achievers/timeline (accessed May 2014).

8 Hobbins P, Hillier K. Isolated cases? The history and histiography of Australian medical research. Health History 2010; 12: 1-17.

9 National Health and Medical Research Council. Measuring up 2013. NHMRCsupported research: the impact of journal publication output 2005-2009. Canberra: NHMRC, 2013.

10 Butler L, Biglia B, Burke P. Australian biomedical research: funding acknowledgements and performance. Canberra: National Health and Medical Research Council, 1998.

11 National Health and Medical Research Council. Statement on scientific practice. Canberra: NHMRC, 1990.

12 Australian Vice-Chancellors' Committee. Guidelines for responsible practice in research and problems of research misconduct. Canberra: AVCC, 1990.

13 National Health and Medical Research Council, Australian Research Council, Universities Australia. Australian code for the responsible conduct of research. Canberra: NHMRC, 2007. http://www.nhmrc.gov.au/files_nhmrc/ publications/attachments/r39.pdf (accessed May 2014).

14 National Health and Medical Research Council, Australian Research Council, Australian Vice-Chancellors' Committee. National statement on ethical conduct in human research. Canberra: NHMRC, 2007. http://www.nhmrc. gov.au/guidelines/publications/e72 (accessed May 2014).

15 National Health and Medical Research Council. Statement on human experimentation. Canberra: NHMRC, 1966.

16 National Health and Medical Research Council. Australian code of practice for the use of animals for scientific purposes. Canberra: NHMRC, 1969.

17 National Health and Medical Research Council, Australian Research Council, Universities Australia, Commonwealth Scientific and Industrial Research Organisation. Australian code for the care and use of animals for scientific purposes. 8th ed. Canberra: NHMRC, 2013. http://www.nhmrc.gov.au/ guidelines/publications/ea28 (accessed May 2014).

18 National Health and Medical Research Council. Values and ethics: guidelines for ethical conduct in Aboriginal and Torres Strait Islander health research. Canberra: NHMRC, 2003. http://www.nhmrc.gov.au/guidelines/ publications/e52 (accessed May 2014).

19 Nobleprize.org. All Nobel laureates in physiology or medicine. http://www. nobelprize.org/nobel_prizes/medicine/laureates (accessed Jun 2014).

20 Butler L, Biglia B. Analysing the journal output of NHMRC research grants schemes. Canberra: National Health and Medical Research Council, 2001.

21 Butler L. NHMRC-supported research: the impact of journal publication output. Canberra: National Health and Medical Research Council, 2003.

22 Butler L, Biglia B, Henadeera K. NHMRC-supported research: the impact of journal publication output 1999-2003. Canberra: National Health and Medical Research Council, 2005

23 Butler L, Henadeera K. Measuring up 2009: NHMRC-supported research the impact of journal publication output 2002-2006. Canberra: National Health and Medical Research Council, 2009.

24 Australian Institute of Health and Welfare. Health expenditure Australia 2011-12. (AlHW Cat. No. HWE 59; Health and Welfare Expenditure Series 50.) Canberra: AlHW, 2013.

25 Wills PJ (Chair). The virtuous cycle: working together for health and medical research. Health and medical research strategic review. Canberra: Commonwealth of Australia, 1999. http://www.health.gov.au/internet/ main/publishing.nsf/Content/hmrsr.htm (accessed May 2014).

26 Grant J (Chair). Sustaining the virtuous cycle for a healthy, competitive Australia. Investment review of health and medical research. Executive summary. Canberra: Commonwealth of Australia, 2004. https://www. health.gov.au/internet/main/publishing.nsf/Content/health-hsidinvestreview/\$FILE/Executive_Summary.pdf (accessed May 2014).

27 McKeon S (Chair). Strategic review of health and medical research. Final report. Canberra: Commonwealth of Australia, 2013. http://www. mckeonreview.org.au/downloads/Strategic_Review_of_Health_and Medical_Research_Feb_2013-Final_Report.pdf (accessed May 2014).

28 Bernstein A (Chair). Independent review of the NHMRC research funding process. 23-25 October 2007. Canberra: NHMRC, 2007. http://consultations. nhmrc.gov.au/files/consultations/drafts/resources/research-fundingbernstein.pdf (accessed May 2014).

29 Nutbeam $D$ (Chair). Report of the review of public health research funding in Australia. Canberra: NHMRC, 2008. http://www.nhmrc.gov.au/_files_ nhmrc/file/research/phr/Nutbeam.pdf (accessed May 2014).

30 Zerhouni E (Chair). An international perspective on the National Health and Medical Research Council's research strategies. 28-30 January 2008. Final report. Canberra: NHMRC, 2008. http://www.nhmrc.gov.au/files nhmrc/ file/research/phr/research-strategies-Zerhouni.pdf (accessed May 2014).

31 American Society for Cell Biology. San Francisco declaration on research assessment. 2013. http://am.ascb.org/dora (accessed May 2014). 